\title{
Wicked Futures: Meaning, Matter, and the Sociology of the Future
}

\begin{abstract}
Sociologists and futurists have come to see that 'fabrications' of the future as entirely open to being remade in the present have become more difficult to sustain in a complex and contingent world. Rather, new and more nuanced conceptualizations of the future are required. To contribute to that task, I draw inspiration from Rittel and Webber's 1973 paper in which they analyze social problems as 'wicked problems' to explore how sociologists have found the future to be difficult and tricky, both conceptually and empirically and have sought to overcome those difficulties through various analytical strategies. I discuss the onto-epistemological status of the future in sociology, tracing major shifts in theorizing of the future and suggest that what makes the future so wicked - so difficult and pernicious - is that it is an 'entanglement of matter and meaning'. In doing so, I draw on insights from STS (science and technology studies) and other fields of inquiry to propose a new conceptual language in which to do the sociology of the future.
\end{abstract}

Keywords: Futures, Sociology, STS, wicked problems

Funding statement: I received no funding in support of the work reported on in this paper.

\section{Introduction}

On my first visit to New York City in 2014, I went to Corona Park to discover what remained of what was once the future. Fifty years earlier, the World's Fair had occupied this site at which the likes of General Motors, IBM, , and Walt Disney projected their techno-utopian visions of the future American life. Yet, in many ways it was the conflicts and social movements beyond the Fair itself which shape that future life so much more (Samuel 2007). The World's Fair took place at the point Franco Berardi (2011) argues was the cultural high water mark of the 'myth of the progressive future' that characterized the twentieth century - a progressive future defined in terms of the extension of liberal democracy and social welfare, and the power of technoscience to meet human needs and wants. Berardi sees that, in this sense, the future is over - the hopes of progress dashed (at least in the West), the utopian imagination turned dystopian. He claims that people have lost all trust in [... the future: [it $]$ no longer appears as a choice or a collective conscious 
action, but is a kind of unavoidable catastrophe that we cannot oppose in any way' (Berardi 2011: 126). The New York's World Fair is now imbued with a poignant nostalgia for a past future that was, when one stops to think about it, supposed to be the present that we are living in today. However, the Fair's exhibitors' imaginings of how our life would be like are mostly unrealized.

In the decade that the New York World's Fair took place, a few sociologists in both the US and Britain responded to the writing of various futurists such as Fred Polak and Bernard de Jouvenel to argue the case for a sociology of the future (Bell and James Mau 1971, Young 1968). These sociologists sought legitimacy for their interest in the future by looking back to the work of the very first generation of sociologists. During the emergence of the discipline in the nineteenth century, Auguste Comte,along with Karl Marx and Fredrich Engels were concerned with both forecasting and actively shaping the future (Manuel 1964). Famously, Marx called on philosophers to not only interpret but to change the world (Marx 1969). While Manuel (1964: x) characterizes the work of Comte and his contemporaries in France as amounting to 'wild, impractical fantasies', they were committed to the idea that what would become known as sociology should address how to bring a better future into being. While Marx and Engels did not produce any kind of utopian blueprint as such, their view of what a better future should look like, and the steps needed to achieve it, became, as we know, a highly significant and contested one (Levitas 1990). The rekindling of sociological interest in the future in the 1960s was shortlived and the sociology of the future did not establish itself as a legitimate sub-field (Bell 1999). In light of the perceived failure of Marxist anticipations of the future, John Urry (2008) claims that sociologists retreated from making predictions themselves and became weary of imagined alternative futures as misguided or obfuscating today's social and economic struggles. Despite this relative failure, since the late 1990s new strands of scholarship on the future have come from STS, mobilities research and social theory of time. Today, as Barbara Adam (2011: 592) argues, 'a future-less sociology is increasingly hard to defend in a world where socio-scientific products and their effects extend ever further futures while temporal perspectives and concerns continue to narrow'.

For this group of scholars contemporary futurity looks very different to that of the 1960s: rather than a set of progressive futures, we live in a time of what I call wicked futures. In adopting this language of wickedness, I am allude to Horst Rittel, who coined the expression 'wicked problem' to refer to that 'class of social system problems which are illformulated, where the information is confusing, where there are many clients and decision 
makers with conflicting values, and where the ramifications in the whole system are thoroughly confusing' (Churchman 1967: 141). Rittel co-authored with Melvin Webber (1973) a significant paper in which they elaborate on this original idea of the wicked problem and delineate its defining features. ${ }^{2}$ For them, 'open societal systems' problems (the example they give is that of poverty) are wicked in the sense of being malignant, vicious or tricky in contrast to scientific problems which they characterize as 'tame', 'benign' and ultimately solvable. They note that describing a wicked problem is difficult not least because each wicked problem is a symptom of another (intractable) problem; such problems are never solved only re-solved time and again, and what stops work on tackling them are resources or time or political will; further, their resolution is judged not by objective criteria but by different social actors' own judgements of what is 'good' or 'good enough' or 'bad' or 'worse' compared to another and consensus is not likely to be reached; every re-solution creates consequences, some or many of which are unintended and unforeseen; and there is no fixed number of available re-solutions available to be tried out to re-solve these problems.

Applying their characterization of wicked problems to some of the wicked futures we face today, such as anthropomorphic climate change, would seem apt. However, it is not my aim in this paper to do so. I keep several different meanings of the term wicked in play to reflect on how the term wicked, with reference to character or action, also means actually or potentially harmful, destructive, disastrous, or pernicious; difficult or dangerous; and, crucially for my purposes here, once meant 'difficult to do something with'. It is this last admittedly now obscure - meaning that interests me the most in the first part of this paper, in which I explore how sociologists have found the future 'difficult to do something with', both conceptually and empirically and have sought to overcome those difficulties through various analytical strategies. I discuss the onto-epistemological status of the future in sociology, tracing major shifts in theorizing of the future that engage with the vexed question of whether the future should be understood as imaginary, in terms of being 'of the mind', or as 'real', as having material form in the present. Given the constraints of space, my discussion will not address the nevertheless interesting work being done in cognate fields such as geography on anticipation (see Anderson 2010).

Drawing on this review of existing work I then diagram my own contribution to conceptualizing the future in sociology. I suggest that the wickedness of the future - in terms of how it is characterized as difficult, pernicious and dangerous is to be understood by the way that the future is enacted through material-discursive practices. In doing so, I draw 
on insights from STS (science and technology studies) and other fields of inquiry to propose a new conceptual language in which to do the sociology of the future that problematizes established onto-epistemological distinctions between what is imagined and what is real. In conclusion, I reflect on the relevance of this approach for engaging with our own contemporary wicked futurity.

\section{Sociology and the Wickedness of the Future}

Bell and Mau's Sociology of the Future, published in 1971, marks a significant contribution to twentieth century sociological scholarship on the future. In contrast to Parsonian functionalism and positivism which were dominant forces in US sociology at the time, they drew inspiration from the science of cybernetics and made an impassioned plea for sociologists to take seriously their role in not only anticipating the future but also in bringing about a 'peaceful and sustainable' one. They conceive of society as 'not only repetition of social interactions and obligations organized by time and space, but also a matter of emergence revealed in human expectations, hopes and fears for the future, choices and decisions' (Bell 1999: 306). In short, as Bell (1999: 308, 304) argues in his later work, society is expectation, in which the future is more or less open to human will, that people are active agents in creating their own lives' and that 'the present is the domain of choice, decision and action'.

Bell and Mau recognize that the future poses an onto-epistemological problem to sociology. How does a sociologist study the 'not yet', that which has not yet happened, which has not taken material form in the present time? What counts as knowledge of the future if the future is not considered as already pre-existing? Unlike the Ancient Egyptians or Greeks, for these American sociologists of the mid-twentieth century the future does not already exist but is open to being remade through choices and actions of people living in the present. Quoting philosopher Robert Brumbaugh, they argue that:

There is a genuine ontological difference in the kind and the definiteness of being which past facts, present options, and future possibilities possess. Part of this difference can be summarized by the assertion that there are no past possibilities, and there are no future facts. (Brumbaugh in Bell and Mau 1971: 9)

In other words, the past is the domain of completed and achieved actions, although our knowledge and understanding of these actions may change over time as we gain more insight into what happened. Conversely, the future is the domain of what-is-yet-to-come. 
Bell and Mau (1971: 11) state that the future is real 'to the extent to which present alternatives or possibilities for the future are real' and these can be known by analyzing 'images of the future' and how these orient social action.

Following Polak (1973 [1951]), Bell and Mau place 'images of the future' as central to their account of social change. Polak argues that in the histories of Middle Eastern and European cultures there have been two dominant images of the future: the eschatological - the religious belief in the violent destruction of our present world and the establishment of a new order such as the 'Kingdom of Heaven' - and the utopian - the belief that a new order can be established here on Earth through the actions and choices of human beings. Over time, Polak argues that there has been a major shift in these cultures in how people have viewed the future - from seeing it as fixed and in the power of the gods or God to control, to something which they could shape according to their own desires. However, it is the elite of a society at any given time who produce images of the future and these images reflect their own values and work not only on a cognitive basis but also invoke emotional responses and can be aesthetically pleasurable. For Polak, images of the future are bound up with social change: the 'rise and fall' of such images precedes the collapse of cultures or entire civilisations.

Bell and Mau utilize a 'cybernetic-decisional model' of society as a way to analyse how images of the future are implicated in change in contemporary society. They define images as being 'expectation [s] about the state of things to come at some future time' (Bell and Mau: 23). Through a series of feedback loops, Bell and Mau propose that beliefs about the past and the present, which reflect societal values, shape the images of the future that are made, which then inform the decision-making process that leads to action that produces the 'actual future'. This, they note, is likely to depart from the images produced of what it will be like - and this 'actual future' which people experience then feeds back into the process of making new images of the future. Through this cybernetic model of societal decisionmaking they emphasize how, with ever-increasing human mastery over Nature, society will become more rational and subject to 'deliberate planning of political, economic, social and cultural change' (Bell and Mau 1971: 24).

In sum, to address the difficulties of studying the 'not-yet', Bell and Mau provide a representational account of the future: the future is real in so far as social actors produce representations of the future which have an effect on others' actions in the present. As with other representationalist accounts, they face a second difficulty in connecting up present 
representations of the future with what is done in practice. They acknowledge that this is a problem since there are always competing images of the future which different social groups produce, some of which they suggest might even be unstated. In the end, they leave open questions about how images of the future actually make their way into decision-making processes and ultimately help shape the way people behave either individually or collectively.

In contrast to Bell and Mau's approach, more recent scholarship in STS on what is called the sociology of expectations has developed an important insight which previous generations of sociologists also recognized about the onto-epistemology of the future: that representing and acting to bring about a future are not distinct and separate from each other (Moore 1966). In 1945 Robert K Merton (1948: 195) articulated the notion of the selffulfilling prophecy to describe the way that 'public [..] prophecies or predictions become an integral part of the situation and thus affect subsequent developments'. While Merton was concerned with social actors making false, baseless predictions which, by influencing others' behaviour, made them come true, scholars of the sociology of expectations begin from a different starting point to explore the performativity of expectations.

As Harro van Lente (1993: 191) argues, 'expectation statements are not only representations of something that does not (yet) exist, they do something: advising, showing direction, creating obligations'. In other words, expectations are also part of the world of action not only of words: they are performative as they are "constitutive" or "performative" in attracting the interest of necessary allies (various actors in innovation networks, investors, regulatory actors, users etc.) and in defining roles and in building mutually binding obligations and agendas' (Borup et al 2006: 289).

While they are performative, expectations are also open to contestation, although efforts to refute or prove that they are warranted are not straightforward. In contrast to Merton, van Lente (1993) suggests that it matters more what an actor is prepared to say publicly for others to hear than whether someone is making a misleading statement about the future or not, or whether they really believe what they are saying. Moreover, as Mads Borup and colleagues (2006) argue the sociology of expectations rejects the realist distinction between expectations of actors and the 'underlying fundamentals' of what something is really worth and whether an untested technology will really work. They argue that it is 'highly problematic to calculate 'the real worth' of something independently from our expectations' 
(Borup et al 2006: 289) or to consign a claim about its potential as merely "hyperbole" (see also Hedgecoe 2004).

For van Lente, then, expectations are words that do things: expectations consist of statements which might contain scripts of particular roles to be played by various actors; these are to be found in various media such as press releases, prospectuses, or scientific review articles, and, he suggests, these scripts can be materialized into the design of artefacts. Yet, as Neil Pollock and Robin Williams (2010) argue, taking issue with Merton's notion of self-fulfilling prophecy, it is not the case that any expectation if taken up by the right actors could be materialized. As I noted at the outset the past is littered with failed futures, which did not come to pass in the way their supporters imagined (Geels and Smit 2000). As Mads Borup and colleagues (2006: 295) remark: 'the under-performance of the future is itself to be expected'. Pollock and Williams (2010: 543) turn to Donald Mackenzie's work on the performative role of economics in shaping markets to think about the 'complicated and highly uneven level of performativity associated with expectations'. Mackenzie distinguishes three levels of performativity: generic performativity, whereby theories when they are applied have little or no observable effect; effective performativity: when applied theories do 'make a difference'; and Barnesian performativity, which is a practical use of economics that, in having an effect on economic processes, makes those processes more like their depiction by economics. Accordingly, Pollock and Williams consider the kinds of statements that actors are making about the future, how robustly they are constructed, contrasting 'provocations' designed to capture interest to more carefully produced expectations.

But the performativity of expectations is not only to be understood in these terms. Expectations, while textual or visual in character, also depend on 'the alignment of a range of heterogeneous human and non-human actors and artefacts into stable socio-technical networks (Hedgecoe and Martin 2003: 330; see also Brown and Michael 2003) for them to be materialized. Authors such as Brown et al (2006) and Martin et al (2008) have offered some suggestive reflections on the relation of imagination and materiality in the sociology of expectations. They suggest that by meeting resistances from materialities, actors are forced to re-imagine and to rearticulate their expectations in relation to changing material conditions. Brown et al (2006: 333) point to the way that 'our futures have historical dimensions'. In their work on of present-day expectations of stem cells for future therapeutic applications, they focus on the 'embedding of innovative imagining in networks of expertise, technique, economy and practice stretching back through time', arguing that 
previous experimental and conceptual models developed by successive researchers since the 1950 s 'prefigure' contemporary expectations of stem cells.

This issue of material resistances resonates with other work in STS on the future, such as by Brown, Rappert and Webster (2000) who draw on insights from the social construction of technology (Mackenzie and Wacjman 1999), to discuss how the future is not simply open but might be closed-off in various ways through technological path dependencies and the 'lock-in' of enduring and complex sociotechnical systems. While not working in STS itself, Urry's (2013, 2008) recent work on climate change, automobility, and energy futures develops a renewed sociological interest in the future that is concerned with technoscientific knowledge, practices and systems. Urry (2008: 275) departs from Bell and Mau's characterization of the future as 'more or less open to human will' and, in contrast to Toffler's 'future shock' discourses of the 1960s, emphasizes instead how 'path dependent mutually adapting systems' become 'locked-in' over long periods of time, including 'embedded social practices and traditions'. ${ }^{3}$ Urry cites the example of projected global warming, in all of its complexity and uncertain consequences as one such locked-in future.

Barbara Adam (2004, 2007, 2011) is also concerned with forms of locked-in futures. In contrast to sociologists writing in the 1960s, Adam does not strike a celebratory tone about human mastery over nature. Challenging the emphasis which Bell gave to human choice and control, she notes that, while today we have increasing power to act in the world, our knowledge of the effects of these actions is far from complete (Adam 2011). Adam (2004) takes issue with the sociological focus on the representation or the performativity of the future in the present. She argues that:

The social psychology of people's motives, intentions and actions guided by visions of the future give us no purchase on the social world of our making that affects not just our future but that of contemporaries across the globe as well as that of successor generations of humans and fellow species for thousands of years to come. (Adam 2004: 10)

Adam contends therefore that it is not enough to only consider what she calls 'present futures' - in other words, statements, images, visions or expectations of the future that are made and circulate in the present. Instead, she and Christopher Groves (2007) argue for a much more materialist account of the future, emphasizing matter over imagination when it comes to sociological thinking about the future. They observe that: 
Matter is our physical world - the earth we live on, the soil that feeds us, the air we breathe, the water we depend on, the body we inhabit, the landscapes and cityscapes we dwell in, the other beings we co-evolved and co-exist with and the socio-cultural world of artefacts $[\ldots]$ From a futures perspective this matter is to be understood not just spatially as frozen in time but also temporally as extended and enduring, interacting and regenerating, decaying and leaving a record, projecting and entailing [..] futurity (Adam and Groves 2007: 178).

In other words, as I noted above, matter extends through time, sustaining path dependencies and lock-ins through the long effects of infrastructure design or the release of carbon dioxide into the atmosphere. This is how, to echo feminist STS scholar Karen Barad (2003), matter comes to matter. Their materialist account of the future contrasts with scholars such as George Herbert Mead (1959 [1932]), who have considered the future as being of the 'mind', of imagination, and thus having no material existence.

However, their materialist account does not only deal with what is manifest in the world. Adam and Groves also argue that sociologists need to critically examine 'latent futures' or 'futures-in-the-making', which are not pre-existing as in traditional sense of fate, but which are nevertheless not merely an aspect of our imagination or desire. These 'latent futures' are real but have not yet fully developed and become manifest and are still in process. These latent futures would include ongoing carbon emissions warming the planet's atmosphere, and altering the chemical composition of the oceans; growing antimicrobial resistance; the long term consequences of nuclear radiation from waste disposal or accident sites; or the effect of ongoing dumping of plastic waste in the environment.

Adam and Groves' notion of latent futures trouble further the onto-epistemological status of the future in sociology as 'such processes are neither mere aspects of our imagination nor territories fully open to our influence, power or desire' (Adam and Groves 2007: 36). These futures do not fit well within Bell and Mau's ontological distinction between what is done and complete - the past - and what is yet to come - the future - that is still not yet 'fact' but only a possibility that could turn out otherwise. Adam and Groves are not suggesting that these are futures are already pre-given, but are processes characterized by certainties and uncertainties, knowables and unknowables. These latent futures therefore pose their own difficulties since they are not amenable to empirical study in the way that representations or performative expectations of the future are able to be analysed. Adam (2011:594) calls for 
sociologists to develop new conceptual tools 'to engage with the "produced future" in progress that is latent and invisible until it materializes as fact sometime, somewhere'.

So far I have addressed how sociologists have found the future to be wicked, encountering difficulties with the onto-epistemological status of the future in their work. I traced a shift from representational thinking about the future to one that emphasizes a particular notion of the performativity of the future, to another that draws attention to latent futures or 'futures-in-the-making'. In the work discussed, there is a clear tension in terms of how to think about the relationship between imagination and materiality, between how futures are represented or performed in discursive practices, and their intended and unintended material consequences. I argue that it is this tension which has made the future wicked for sociology. Building on this work, in the final section of this paper, I explore a new conceptualization of the future. This offers on one level a way out of the current state of wickedness, but, I suggest, it also better characterizes just how wicked the future is when we think about it as the 'entanglement of matter and meaning'.

\section{Futures as 'Entanglements of Matter and Meaning'}

When thinking about the future, I propose that sociologists should abandon the tradition that sees it as the domain of the imaginary and, as such, as having no 'real' or material existence. Building on the work of authors I have discussed so far, a number of whom are also supportive of a materialist understanding of the future, I outline the case for thinking sociologically about the future in material-discursive terms as enacted in practice rather than in representationalist or performative terms as I have addressed so far. My inspiration for this approach comes from a number of sources, both from within STS and beyond from work in political philosophy and cultural anthropology on the concept of the imaginary. In doing so, I seek to challenge the division between the real and the imaginary that permeates the sociology of the future.

Even though, throughout their work, Adam and Groves constantly problematize distinctions between the imaginary and the real, they too tend to reproduce certain understandings of the imaginary that I wish to challenge. The following passage illustrates well their approach to questions of matter and meaning. In their discussion of 'latent futures' as forms of 'virtual futures', they argue that: 
The future as virtuality is therefore not 'virtual reality' in the sense of an unreal simulation of what is real: it is, instead, the latent yet material dimension of that which already exists, and which is always at work, creating patterns for near and unimaginably distant futures. As [it] evolves into new, actual forms it may eventually be lived by and take on significance for those individual 'components' that share in it. When it is lived, once it becomes incorporated in bodies and in the social meanings by which humans project and organise their lives, it may emerge as beneficial or harmful. (Adam and Groves 2007: 174)

In this passage, Adam and Groves describe a process by which latent yet material dimensions of the future begin by lacking both visibility and meaning. Over time, these latent dimensions become 'actual forms' and they become meaningful as they are 'lived'. In practice, this is a complex and deeply contested process as many have documented in relation to global warming. As James Lovelock (2014) observes, as early as the nineteenth century a few scientists understood that the release of carbon dioxide from burning coal would over time begin to warm the planet's atmosphere. However, it took a far longer time, before this matter came to matter, before it emerged as a matter of concern (Latour 2004). Yet, one problem with this version of matter and meaning is that it implies a process whereby matter precedes meaning - a latent material process becomes meaningful only after a certain time and presumably under certain conditions. Arguably, what this overlooks is how other meanings - for example, that the future is a 'resource' to be exploited for the gain of those living in the present or that Nature is inexhaustible - might be at work and are deeply implicated in the emergence of such latent processes. As Urry (2013: 239) notes, for instance, 'the twentieth century operated as though that entire century was a free (liquid) lunch, especially of oil which could be burned with impunity'.

Rather than seeing meaning as following from matter, I stress how matter and meaning are entangled with each other. Like Adam and Groves, Karen Barad (2003: 803) argues that social scientists need to give 'matter its due as an active participant in the world's becoming'. Finding her inspiration from the physicist Neils Bohr's work, Barad aims to counters the 'linguistic' or 'semiotic' turns in social theory (to which van Lente saw his work on expectations contributing). She goes further than Brown and colleagues' (2006) argument about how matter might force actors to rearticulate their expectations, saying that 'matter is not a support, location, referent [... for discourse'. Instead, Barad (822) argues that: 'the material and the discursive are mutually implicated [...] The relationship between the material and the discursive is one of mutual entailment. Neither is 
articulated/articulable in the absence of the other; matter and meaning are mutually articulated.'

Barad is not alone in making this kind of argument. Donna Haraway (1987: 1), too, has long been engaged with troubling the boundaries between materialism and idealism through her work on feminist material-semiotics, beginning with her work on the figure of the cyborg as the 'condensed image of imagination and material reality'. Haraway (1985: 592) insists that 'objects in the world' should not be viewed as 'a screen or a ground or a resource' but 'pictured as an actor and agent'. Accordingly, she notes, 'accounts of a "real" world do not, then, depend on a logic of "discovery" but on a power-charged social relation of “conversation"” (Haraway 1985: 592). Haraway (596) playfully suggests that: 'the world resists being reduced to mere resource because it is - not mother/matter/mutter - but coyote, a figure of the always problematic, always potent tie between meanings and bodies'. Her invocation of the coyote figure points to an important insight: that relations of matter and meaning are difficult to do - to conceive of and act with. They rarely come easy. In Haraway's terms, the future is not a 'free resource' open to human will to simply re-fashion , but is wicked - it is difficult, dangerous and tricky to act on - a 'problematic and potent tie' between desires and dreams and the unintended material consequences of our actions (see also Arendt (1958) for a more philosophical reading of the unpredictable relationship between promises and outcomes).

Every materialized future leaves traces that cannot be undone (pace Rittel and Webber), these traces can become path interdependencies that 'lock-in' certain options and become irreversible because resources used in one way cannot be used again. Each future followed is another future not taken. Moreover, we can only come to a (admittedly contingent) verdict about whether our hopes for the future were justified when it has already past; so we can only act in the present in hope or take pre-emptive action to avoid undesirable futures. As Bell (1999: 303-4) observes: 'there are few - if any - final solutions. Rather there are corrections, and, then, new designs and more corrections'. In short, our choices such as they are constituted are made without a basis for comparison. We struggle to anticipate or fully know the future consequences of our actions or those of others. We might act with the best of intentions but our best intentions can produce unintended consequences, unforeseen effects, and unanticipated events can stall, complicate, or end prematurely our dreams. Moreover, the timescale over which futures unfold adds a further complication since what might appear relatively benign over a fifty to hundred year duration, might become far more pernicious over a much longer time. ${ }^{4}$ 
What all this points to then is an understanding of how the future is enacted by what Adam (2008: 7) calls 'socio-political, legal, scientific, economic and everyday performative, enacting practices'. This version of performativity is not the same as that found in Donald Mackenzie's work but is the one Judith Butler (1993) articulates in terms of mundane, everyday re-enactments and repetition of certain practices as creating lived realities. It is this understanding of performativity which scholars, associated with the so-called 'ontological turn' in STS (see Woolgar and Lezuan 2013), have taken up to move away from questions of representation or knowledge to address the "way that objects are enacted in practice' (Mol in Woolgar and Lezuan 2013). These scholars are interested in world-making and their insights might be useful for future-making as well. As Steve Woolgar and Javier Lezuan (2013: 326) note, 'material objects [... should in principle be treated as practical achievements, as qualities also "enacted in practices”. In other words, “"materiality” [.. needs to be understood as the contingent upshot of practices, rather than a bedrock reality' on which meanings are then articulated.

Elizabeth Shove and colleagues (Shove et al 2013) have been very much engaged with thinking about practice, building on a long tradition of work in sociology. Shove et al (2013: 7) define practice as a 'temporally and spatially dispersed nexus of doings and sayings', which are sustained over time by their repeated performance, entailing both human actors and material entities. An important part of this focus on practice is the meanings people give to them and how they make sense of them. This connection between meaning and practice is reflected in debates beyond sociology about the concept of the imaginary.

Since Immanuel Kant, scholars have tended to distinguish the imaginary from what is real, but more recent work such as that by philosopher Charles Taylor (2003: 32) challenges the opposition between

Ideas and material factors as rival causal agencies. In fact, what we see in human history is ranges of human practices that are both at once, that is, material practices carried out by human beings in space and time, and very often coercively maintained, and at the same time, self-conceptions, modes of understanding.

As opposed to seeing the imaginary as that which is 'of the mind', Taylor (2002: 106) argues for a socialized notion of the imaginary, which describes 'the ways in which people imagine their social existence $[. .$.$] how things go on between them and their fellows, the$ expectations that are normally met, and the deeper normative notions and images that underlie these expectations.' This imaginary 'enables us to carry out the collective practices 
that make up our social life' (Taylor: 106). As Taylor's language of expectations implies, this imaginary is not only about the present but is also very much about the future as part of our everyday lives. The cultural anthropologist Arjun Appadurai (1996:29) makes a similar argument that imagination should be understood as 'an organized field of social practices'. So, while from Mead onwards scholars have tended to treat the future as being only 'of the mind' because it is a time that people imagine beyond the reality of their present, Taylor and Appadurai's work provides an alternative way to think about how imagination is a social practice, and is thus implicated in enacting the future in a different way.

In sum, bringing together these different bodies of work from STS and other fields, I have begun to outline the case for an understanding of the future as enacted through particular material-discursive practices. Discursive constructions of the future are not simply imaginative in the traditional sense but are thoroughly social practices. These practices are in turn implicated in forming certain materialities and with letting loose both intended and unintended consequences. But, having now outlined this approach in diagrammatic terms given the space available, what might this mean for sociology's engagements with contemporary futurity?

Woolgar and Lezaun (2013: 326) argue that STS scholars' concern with ontology has been bound up with the field's long standing commitment to the notion that 'it could be otherwise'. Being concerned with the practices of world-making also prompts questions about in which world would you like to live, and what can you do to bring such a world into being?' This would strike a chord with some sociologists of the future such as Wendell Bell who argues that sociologists should not only make 'contingent predictions of specific alternative futures' (Bell 1999: 306) but also create their own images to help bring out a better future. While acknowledging that sociologists have become weary of imagined alternative futures as misguided or obfuscating today's social and economic struggles, Urry too sees that sociology has an important role to play in challenging policy advisors' often technologically deterministic and sociologically deficient accounts of future change. Adam and Groves (2007) argue that sociologists and others need to adopt the standpoint of a future present in order to figure the potential impact on future generations of processes set in train now. For them, this can not only be an act of imagination (as they understand it), but must relate to 'deeds and processes already on the way' (Adam and Groves: 176). This is as much an ethical as intellectual position as 'only the standpoint of the future present, we need to appreciate, enables us to accompany our actions to their potential destinies and know 
ourselves as responsible for their time-space distantiated impacts' (Adam and Groves: 176) . But how to do this?

In his recent work, Urry has developed scenarios of alternative, possible social futures, with the aim of imagining a form of social life that could emerge to better manage the impact of global warming or fossil fuel depletion. In crafting such accounts of alternative futures, Urry is emphasizing the importance of practices and the complexity of interdependent sociotechnical systems. However, how successfully these 'sociologies of the future' help us to imagine how it could be otherwise is debateable. In Haraway's terms, taking the standpoint of a future present as Adam and Groves call for, absolutely require imaginative figurations replete with metaphor, visual images, and stories - to bring that future present into being and to connect it to what is in process today. As Haraway appreciates, often science fiction writers are well placed to conjure future presents in a way that often convey important issues of transgenerational responsibility. Take, for instance, how in News from the Squares (the second book in his "utopian” trilogy), British author Robert Llewellyn (2014) depicts a scene in which the narrator from our present, who has travelled to a future present (to a society, incidentally, which is led exclusively by women), joins a museum tour. On this tour he is introduced to his present as their distant past: he finds how this society has had to assume responsibility for the nuclear waste produced in his time. In caverns below Trondheim are thousands of barrels of radioactive material, decaying slowly, leaking out into the earth around them; a counter reads that there are 49,782 years left before the waste is no longer dangerous. Llewellyn captures well the dissonance that the narrator experiences between his expectations of the benefits of nuclear power and the way that members of this future society see it as a failed technology and a pernicious legacy.

In a time in which, as Berardi suggests, western cultural imagination has turned dystopian, Llewellyn's writing marks an attempt to articulate a renewed utopianism by imagining, as he remarks, 'a world where we eventually get it right $[.$.$] we don't rip the planet to shreds$ to maintain our way of life and we don't need to rely on endless growth to achieve contentment. In the current turmoil it could be argued that such optimism could only be suggested by a fool, indeed, such benign developments may not be very likely, but we may need to be reminded that they are entirely possible' (Llewellyn 2009). Llewellyn is indeed an optimist compared to how sociologists see the future. While Urry (2013: 240) figures that: 'the only possible way forward is through a pervasive powering down to a "low carbon civil society", he goes on to acknowledge that: "the odds of this "low carbon civil society" [...] are very low, but fortunately not quite zero'. Yet this is far more positive than Berardi (2011) 
who views the future as an 'unavoidable catastrophe', with 'no way out'. Similarly, Slavoj Zizek (2011) is at best ambivalent about resolving our wicked futures. Sharing Berardi's sense of impending catastrophe, he argues that global capitalism itself is reaching the apocalyptic end-point because of various ecological crises, the consequences of biogenetic modification of human and non-human species, global and local struggles over increasingly scarce resources, and the intensification of economic and social inequalities. As Urry (2008: 276) puts it pithily: 'there are no good outcomes, only degrees of bad'.

Part of the difficulty is that even with figuring future presents as the outcomes of latent processes today, 'knowing what will engender desired global change is almost impossible'(Urry 2008: 266). This is in part because, as Fredric Jameson (1982: 152) argues, 'the present moment [is] unavailable to us for contemplation in its own right because the sheer quantitative immensity of objects and individual lives it comprises is untotalizable and hence unimaginable'. Zizek also notes that any attempt at resolving global warming and its effects requires making a significant change to contemporary capitalism. Yet, he wryly observes (2010: 334), quoting Jameson again, that: “it is easier to imagine a total catastrophe which ends all life on earth than it is to imagine a real change in capitalist relations"'. However, his analysis is not a call to do nothing but to do something truly radical: there is no middle ground when responding to the threat of global warming.

In short, then, figuring future presents is one thing, finding our way through the tangles of matter and meaning in our wicked futurity is another thing altogether.

\section{Conclusion}

Arguably, there can be no conclusions to a paper on the future. There is only a temporary resolution of the issues raised in the preceding pages: in this paper, I adopted the language of wickedness in order to explore how sociologists have grappled with tensions in the concept of the future in their work over the past half-century. I traced major shifts in sociological thinking from representationalism, performativity, to materialism and diagrammed my own account of a material-discursive understanding of the future that attempts to break out of existing onto-epistemological categories. While this account is no more than an indicative one, designed to prompt further debate, I contend that this approach to the future builds on and departs from existing sociological analyses and connects debates about the future to concerns of other scholars in sociology, STS and beyond. As sociologists both past and present argue persuasively, sociologists need to 
engage with the future, both conceptually and empirically, and my aim has been to initiate a new contribution to that engagement.

\section{Notes}

1. However, we might question the separation between tame scientific and wicked social problems in the first place. As Xiang (2013: 2) comments: 'the ubiquity of wicked problems is the norm, and present in almost every pressing issue area that matters to $[, . .$.$] human society today, such as global climate change, sustainability,$ stem cell research and usage, resource management, terrorism, and urbanization'.

2. By path dependence, historians of technology are describing the influence past events have over 'technological paths' adopted, with the consequence that adopting alternative paths becomes more difficult and costly to do over time (see Mackenzie and Wajcman 1999)

3. I am grateful to an anonymous reviewer of the paper for this observation.

\section{References}

Adam B, Groves C. (2007), Future Matters: Action, Knowledge, Ethics, Amsterdam: Brill Books.

Adam, B., (2004) 'Towards a New Sociology of the Future', unpublished paper, available at: http://www.cf.ac.uk/socsi/futures/newsociologyofthefuture.pdf.

Adam, B. (2011), 'Wendell Bell and the Sociology of the Future: Challenges Past, Present and Future', Futures, 43(6):590-5.

Anderson, B., (2010), 'Preemption, Precaution and Preparedness: Anticipatory Action and Future Geographies', Progress in Human Geography, 34(6):777-98.

Appadurai A., (1996), Modernity al Large: Cultural Dimensions of Globalization: Minneapolis: University of Minnesota Press.

Arendt, H. (1958) The Human Condition, Chicago: University of Chicago Press Barad K. (2003), Posthumanist performativity: toward an understanding of how matter comes to matter. Signs, 28(3):801-31.

Bell, D. (1973), The Coming of the Post-industrial Society: A Venture in Social Forecasting, New York: Basic Books.

Bell W., (1999), 'The Sociology of the Future and the Future of Sociology', Sociological Perspectives, 39(1):39-57. 
Bell W, Mau JA (eds), The Sociology of the Future: Theory, Cases and Annotated

Bibliography. New York: Russell Sage Foundation.

Berardi FB., (2011), After the Future, G. Gensoko and N. Thoburn (eds), A. Bove, M.

Cooper, E. Empson, Enrico, G. Mecchia and T. Terranova (trans), Edinburgh: AK Press

Borup M, Brown N, Konrad K, Van Lente H., (2006), 'The sociology of expectations in science and technology', Technology Analysis \& Strategic Management, 18(3):285 - 98.

Brown N. (2003), 'Hope against Hype: Accountability in Biopasts, Presents and Futures', Science Studies, 2:3-21.

Brown N, Kraft A. and Martin, P., (2006) 'Blood Ties: Banking the Stem Cell Promise', Technology Analysis \& Strategic Management, 18(3):313 - 27.

Brown N, Michael M., (2003), 'A Sociology of Expectations: Retrospecting Prospects and Prospecting Retrospects', Technology Analysis and Strategic Management, 15 (1):3-18. Brown N, Rappert B, Webster A. (eds), (2000), Contested Futures: A Sociology of Prospective Technoscience, Aldershot: Ashgate.

Butler J., (1993), Bodies that Matter: On the Discursive Limits of "Sex", New York and London: Routledge.

Churchman, C. West, (1967), 'Wicked Problems', Management Science, 14 (4): 141-142 Coyne R., (2005), 'Wicked Problems Revisited', Design Studies, 26(1):5-17.

Dennis, K. and Urry, J., (2009), After the Car, Cambridge: Polity

Geels F.W. and Smit W.A., (2000) 'Failed Technology Futures: Pitfalls and Lessons from a Historical Survey. Futures, 32:867-85.

Haraway D. (1987), 'A Manifesto for Cyborgs: Science, Technology, and Socialist

Feminism in the 1980s', Australian Feminist Studies, 2(4):1-42.

Haraway D. (1988) 'Situated Knowledges: The Science Question in Feminism and the Privilege of Partial Perspectives', Feminist Studies, 575-99.

Hedgecoe A, Martin P., (2003), The Drugs Don't Work: Expectations and the Shaping of Pharmacogenetics', Social Studies of Science, 33 (3):327-64.

Hedgecoe, A. (2004) The Politics of Personalized Medicine: Pharmacogenetics in the Clinic, Cambridge: Cambridge University Press.

Jameson F., (1982), 'Progress versus Utopia; Or, Can We Imagine the Future? Science Fiction Studies, 9(2):147-58.

Levitas R., (2011), The Concept of Utopia. London: Peter Lang.

Llewellyn R., (2013) News from the Squares. London: Unbound 
Mackenzie D. (2003) 'Constructing a Market, Performing Theory: the Historical Sociology of a Financial Derivatives Exchange', American Journal of Sociology, 109(1):107-45.

Mackenzie D. and Wajcman J., (1999 [1985]) 'Introductory essay: the Social Shaping of Technology', in Mackenzie D. and Wajcman J. (eds) The Social Shaping of Technology, 2nd ed. Cambridge: MIT Press: 3-27.

Manuel FE., (1962) The Prophets of Paris, Cambridge: Harvard University Press Martin, P., Brown, N. and Kraft, A., (2008), From Bedside To Bench? Communities of Promise, Translational Research and the Making of Blood Stem Cells,' Science as Culture, $17(1): 29-41$.

Marx, K., (1969) Theses on Feuerbach in Marx and Engels Selected Works, Moscow:

Progress Publishers

Mead G.H., (1959 [1932]) The Philosophy of the Present, Murphy A.E. (ed.) La Salle: The Open Court Publishing Company.

Merton R.K. (1948), 'The Self-fulfilling Prophecy', The Antioch Review, 8(2):192-210.

Mol, A., (2002) 'The Body Multiple: Ontology in Medical Practice', Durham: Duke University Press

Moore, W.E., (1966), 'The Utility of Utopias', American Sociological Review, 31(6):765-72.

Moser, I., (2008), 'Making Alzheimer's Disease Matter. Enacting, Interfering and Doing Politics of Nature’, Geoforum, 39(1):98-110.

Perry, J. (2015), 'Climate Change Adaptation in the World's Best Places: A Wicked Problem in Need of Immediate Attention', Landscape and Urban Planning, 133(0):1-11. Polak F., (1973), The Images of the Future, New York: Elseviere.

Pollock, N., and Williams, R., (2010) 'The Business of Expectations: How Promissory Organizations Shape Technology and Innovation', Social Studies of Science, 40(4):525-48. Rittel, H.W. and Webber, M.M., (1973) 'Dilemmas in a General Theory of Planning', Policy Sciences, 4(2):155-69.

Samuel, L., R., (2007) The End of the Innocence: The 1964-65 New Tork World's Fair, Syracuse: Syracuse University Press.

Shove, E. (2010) 'Beyond the ABC: Climate Change Policy and Theories of Social Change', Environment and Planning A, 42(6):1273.

Shove, E., Pantzar, M. and Watson, M., (2012) The Dynamics of Social Practice: Everyday Life and How it Changes: London: Sage. .

Taylor, C. (2004) Modern Social Imaginaries, Durham: Duke University Press.. 
Toffler, A., (1970), Future Shock: A Study of Mass Bewilderment in the Face of Accelerating Change, London: The Bodley Head.

Urry, J., (2008) 'Climate Change, Travel and Complex Futures', The British Journal of Sociology, 59(2):261-79.

Urry, J., (2010), 'Consuming the Planet to Excess', Theory, Culture \& Society, 27(2-3):191212.

Urry, J. (2011) Climate change and Society, Cambridge: Polity.

Urry, J., (2013), Societies Beyond Oil: Oil Dregs and Social Futures, London: Zed Books. van Lente, H., (1993) Promising Technology: The Dynamics of Expectations in Technological Developments, Twente: University of Twente.

van Lente, H., Spitters, C. and Peine, A. (2013) Comparing Technological Hype Cycles: Towards a Theory', Technological Forecasting and Social Change. 80(8):1615-28.

Woolgar, S. and Lezaun, J., (2013), The Wrong Bin Bag: A turn to Ontology in Science and Technology Studies? Social Studies of Science, 43(3):321-40.

Xiang, W-N., (2013) 'Working with Wicked Problems in Socio-Ecological Systems: Awareness, Acceptance, and Adaptation', Landscape and Urban Planning, 110(0):1-4. Young, M., (ed) (1968) Forecasting and the Social Sciences, London: Heinemann Žižek, S. (201 1), Living in the End Times, London: Verso 